\title{
The Implementation of Bali Aga Houses and Settlements' Concept on Modern Houses and Settlements in Denpasar City
}

\section{Tri Anggraini Prajnawrdhi}

Laboratory of Architecture and Urban Design, Department of Architecture, University of Udayana, Jimbaran, Bali- 80361, Indonesia

\section{Abstract}

Denpasar as the capital city of Bali is facing high population growth each year from urbanization. One impact of this phenomena is decreasing the land provision for settlement. The growth of new settlements in Denpasar city currently featured a different character from the Balinese Traditional Houses of Bali Apanaga (BAP) in general, both from their forms and appearances; spatial patterns; materials and ornaments used. Contemporary houses in Denpasar are considered as a form of violation from traditional concepts and neglecting local identity. This paper investigates

Corresponding Author: Tri Anggraini Prajnawrdhi

Received: 24 May 2019 Accepted: 25 July 2019 Published: 4 August 2019 Publishing services provided by Knowledge E

(c) Tri Anggraini

Prajnawrdhi. This article is

distributed under the terms of the Creative Commons

Attribution License, which permits unrestricted use and redistribution provided that the original author and source are credited.

Selection and Peer-review under the responsibility of the ISTEcS 2019 Conference Committee. the ideas that are being used in modern houses and settlements in Denpasar today. A case study method was applied to several settlements in Denpasar using a qualitative approach for data analysis. Furthermore, reviews of the significant modern concepts were compared to the idea of BAP and Bali Aga (BA). The results show that significant concepts of forms, as well as the spatial patterns of BA houses and settlement houses which represent Balinese indigenous houses, have been more adopted by well-designed modern houses and settlements in Denpasar than the concept of BAP.

Keywords: concept, land provisions, houses, settlements

\section{Introduction}

In recent days, one of the significant challenges faced in many cities is rapid urbanization; this challenge gave an impact on human welfare and a viable global environment [16]. The increase of population has put massive pressure in the developing countries especially to its urban development. Rapid urbanization is usually accompanied by uncontrolled growth and expansion of the informal sector and poses a significant risk on unique cultural and natural resources stated by Pearson \& Sullivan 1995 [13]. New developments to cater the population growth significantly reduce the green areas for high rise development, then this new development also replaced low rise traditional buildings as well. Population growth in the city center all over the world which basically from urbanization poses a major challenge to environmental sustainability and 
cultural heritage conservation because the new development has to accommodate the population at the same time. Further, these changes then given many problems arise such as the issues of wastewater and beach pollution; lack of clean water; solid waste disposal; thus have created imbalance for the sustainable environment in Bali [21]. Knox \& McCarthy [10] argue that developing countries today is over-urbanization, the main issues that the jobs and housing are not keeping up with the population growth, and the changes from regions and villages are uncontrollable.

Bali is one province in Indonesia with a population growth rate of $2.14 \%$ per year in the past ten years. Based on the growth rate, this growth can be considered as rapid population growth. Denpasar is the capital of Bali Province, faces a very fast rate of population growth every year. The average population growth rate in the last 10 years reached $4.1 \%$ [3], so it can be seen that the city of Denpasar experienced a high population growth rate. With this high population growth rate, it directly increases the need for shelter and all its supporting facilities, thus increasing the demand for land for housing and public facilities. Denpasar has recorded the second highest population growth after Badung regency in Bali, and this growth is based on rapid urbanization and migration from other regencies, and from outside the island of Bali [3]. Denpasar has the highest population increase from urbanization and migration amongst another region in Bali, and it holds $20 \%$ of total migration to Bali. Bali is a small island covering $0.3 \%$ of total Indonesia, and Denpasar city is only covered $2.27 \%$ of total Bali. Bali is one of the best tourist destinations in South East Asia because of its unique landscape, culture, and heritage. Hitchcock \& Putra [9] mentioned that tourism activities had become the most important economic activity to Bali, this activity has brought big income to this island and Bali has become one of the most prosperous provinces in. There are also millions more of local tourist from any other parts of Indonesia to this small island; this condition leads to more population growth to Bali [11]. Thus, it can be seen that the growing population in Bali and Denpasar is also accompanied with the influx of tourists, this culturally rich city is facing a transformation to cope with the demands of additional infrastructure and services [13]. This transformation then changed the original plan for Denpasar, which was built based on Hindu traditions and its architectural code. Moreover, the concept of space, built form, landscape, and urban design is also based on Balinese Hindu concept of the harmonization between God, human and the natural environment.

With the influx of population to Denpasar, then the change of demography from homogeneity to heterogeneity is undeniable. Then, the changed of professions from 
being mostly farmers and fisherman to today fulltime employees in many different sectors include the commercial sector; tourism industry and other linked professions. This condition also has become one issue which needs to be addressed in a built form. This paper explores the impact of the rapid population from urbanization, migration, tourism, the change of professions and demography to a contemporary house in Denpasar. The modern homes in Denpasar considered as the violation of the traditional Balinese Hindu architectural concepts. Thus, this paper investigates the idea of contemporary homes in Denpasar from a few case studies of modern houses. Case study method applied to this study. Observation survey and in-depth interview applied to obtained primary data, while secondary data collected through literature, regulation and local norms. These data both primary and secondary are processed in qualitative content analysis. This paper explored the implementation of Bali Aga (BA) traditional house concept into contemporary houses in Denpasar.

\section{The Concept of Balinese houses}

\subsection{Balinese traditional houses of Bali Apanaga (BAP)}

Understanding the concept of a traditional Balinese house could be seen from two different points of view. Balinese traditional settlements are divided into two categories, namely Bali mainland known as Bali Apanaga or Bali Majapahit and Bali highland called Bali Aga. Bali Apanaga villages are settlements which the population originates from the descendants of the Majapahit kingdom in Java. While the Bali Aga settlement is also known as the Bali Mula, the population of these villages is the indigenous people of Bali before the arrival of communities from the Majapahit Kingdom. The concept of traditional house patterns and settlements is a manifestation of the Balinese people's belief, attitudes, and way of life. Further, the house concept is established based on the way of life of Balinese people, including Hinduism, the norms and customs of the local community, and the nature of the surrounding environment. Hindu as the main religion has become a strong foundation for the settlements arrangement, the spatial pattern of the traditional Balinese houses. According to Sulistyawati [19] that traditional Balinese houses could accommodate a variety of activities for the inhabitant's living needs both physiological and psychological (including traditional activities and religious rituals). Further, Parimin [12] also mentioned that traditional Balinese houses are classified into four attributes which include: sociology; symbolic; morphology; and function. Thus, 
the traditional Balinese houses could accommodate different types of needs of the residents.

Furthermore, there is an critical concept according to Hindu belief which maintains in the harmony of the relationship between humans and their natural environment. Humans are called Bhuwana Alit, and the environment is called Bhuwana Agung. The concept of balance between Bhuwana Alit and Bhuwana Agung is an important concept that has been applied to the settlements of the traditional Balinese communities. This concept educates humans to always maintain harmony between traditional Balinese dwellings and natural environments. This is associated to a Manik ring Cecupu that is human as the content and nature as a container, which should always be maintained harmoniously, it is also embodied as Manik / fetus in the mother's womb [17, 18]. The concept of harmony is not only between humans and their environment but also with God as the creator. Therefore this concept of balance between humans, the environment and the God as the creator is known as a universal concept called Tri Hita Kharana.

In the traditional settlement's setting, there is a concept of Tri Angga which also become one of the essential concepts reflects the harmony of building with humans as its inhabitants. The Tri Angga concept consists of the head (roof) of the building, the body of the building, and the foot (based) of the building. Then, the harmony between building proportion with humans as their occupants is well achieved. The next important concept is Sanga Mandala which is based on the wind direction and also the belief of sacred-profane based on the position of the mountain (as a sacred orientation) and the sea (as a profane orientation) which applied into the traditional settlements. This concept divides the land into nine divisions based on the value of each division (see Figure 1). The idea of Sanga Mandala spatial layout is an important factor for zoning activities and design of buildings in a house courtyard [19]. Activities which are considered as necessary will have a position in north and east area 'Kaja Kangin, and activities which are less important will have a position in south and west 'Kelod Kauh.'

\subsection{Balinese traditional houses of Bali Aga (BA)}

Bali Aga village settlements as previously explained, are located in mountainous or highland areas. This settlement is also known as Bali Mula which can be said to be a native population of Bali. The concept applied in these settlements and traditional houses is a simple concept based on the religion and beliefs of the local community. Besides religion, there are several local traditions from the community also become 


\section{KONSEP ARAH ORIENTASI RUANG}
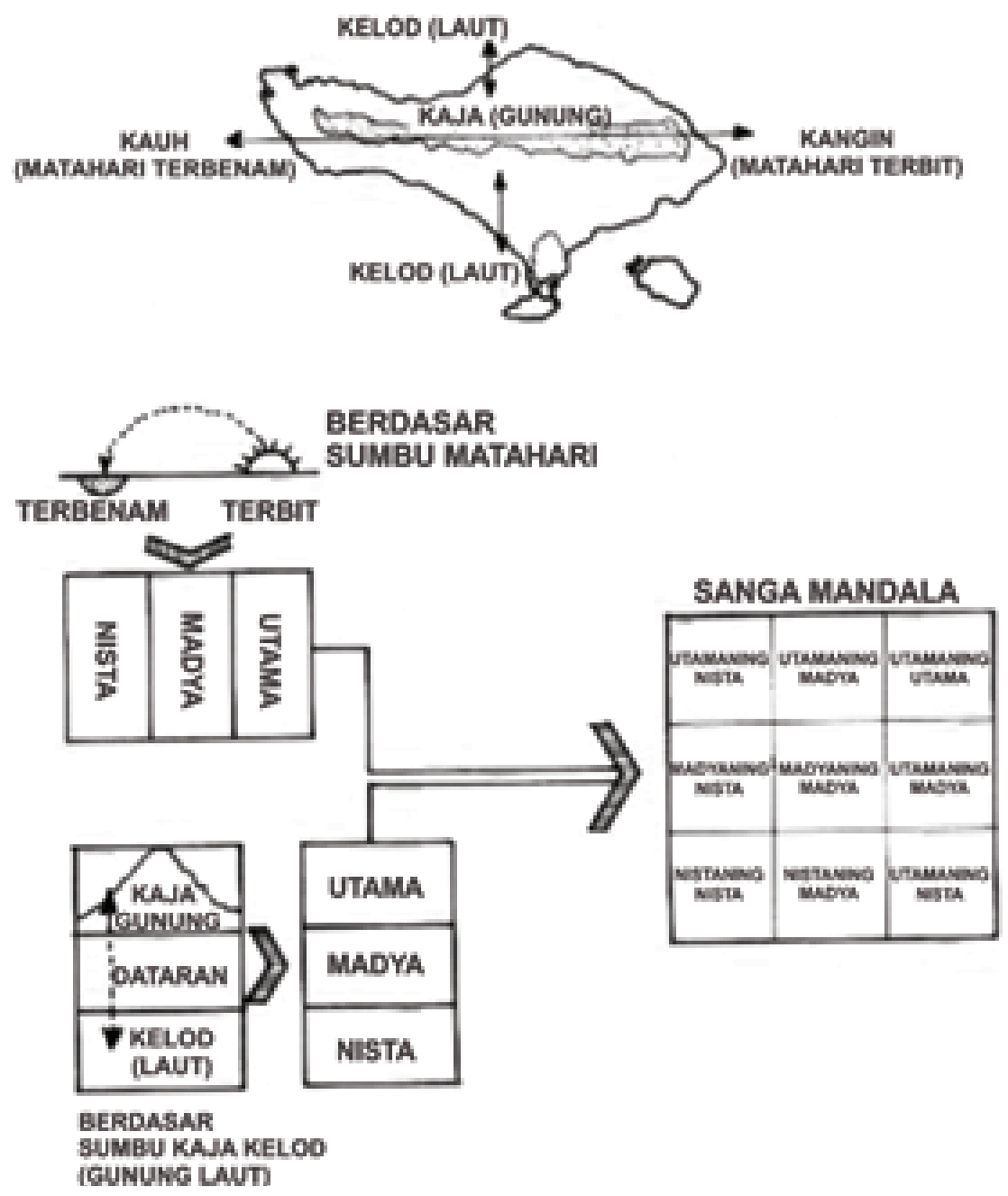

Figure 1: Concept of spatial orientation and Sanga Mandala (source: Budiharjo, 1986).

a foundation that underlies spatial planning and settlement patterns. The central concept which applied to traditional BA houses is a harmonization with nature and the environment. The scale, building materials and the proportion of traditional BA houses are effortless and very integrated with nature and its surrounding environment. One main concept of BA houses is there is no attempt to dominate nature both in terms of building appearance and building's scale. Thus, this also reflects the simplicity of the lifestyle of the BA community [14]. Further, the simple concept also resembles the concept of Tri Hita Kharana which is being used for building and layout of the BAP settlement. The idea of traditional settlements in BA villages do not apply the concepts of Sanga Mandala or Tri Mandala, but rather Dwi Dwi Mandala or Rwa Bhineda. This concept divides the land into only two divisions, namely for the sacred areas and the 
profane areas. This is especially the concept of balance between two opposite poles but becomes harmonious with one another.

The concept of spatial pattern in the traditional BA houses has a simple concept to accommodate all types of activities of its inhabitants. The spaces that are integrated one to another and have a center of the orientation of open space in the center of the house. This concept of orientation resembles the idea of the traditional BAP house pattern, except that the open spaces traditional BA houses located in the building while in BAP as an open space between buildings. Figure 2 shows the difference between the BAP and BA houses layout.

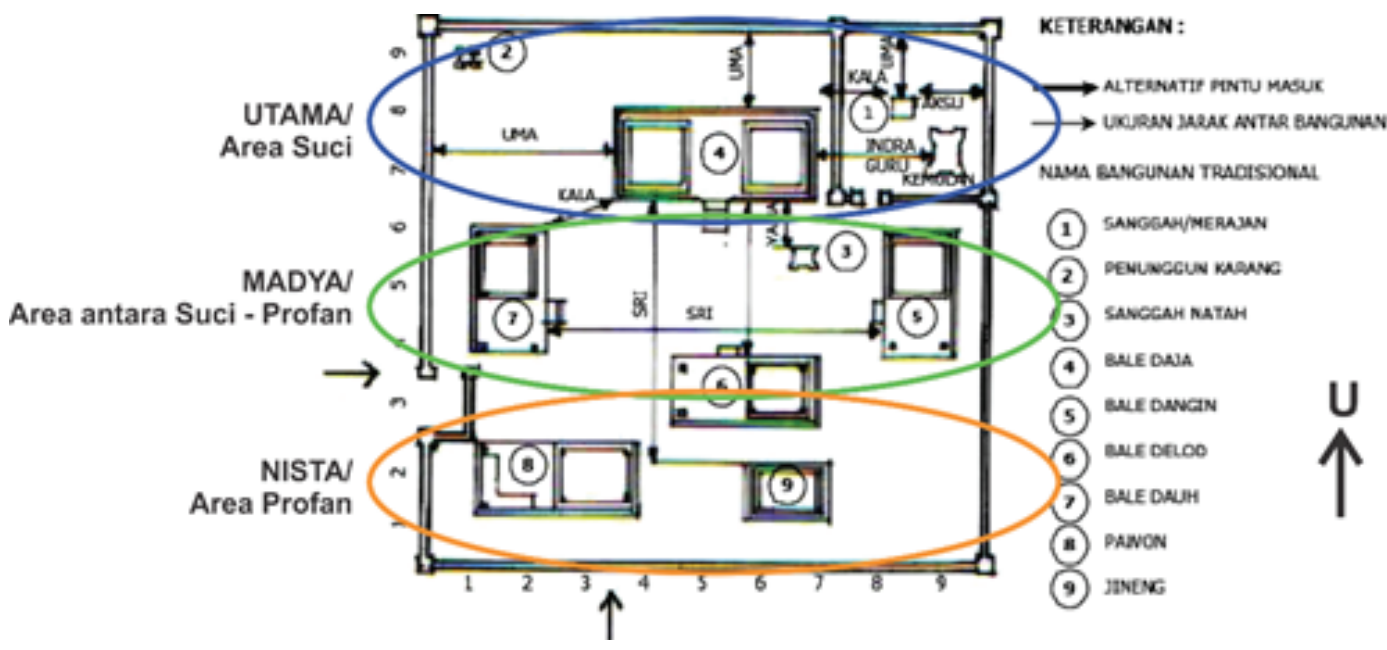

Figure 2: The layout of Bali Apanaga traditional house compound (source: Adhika, 1994).
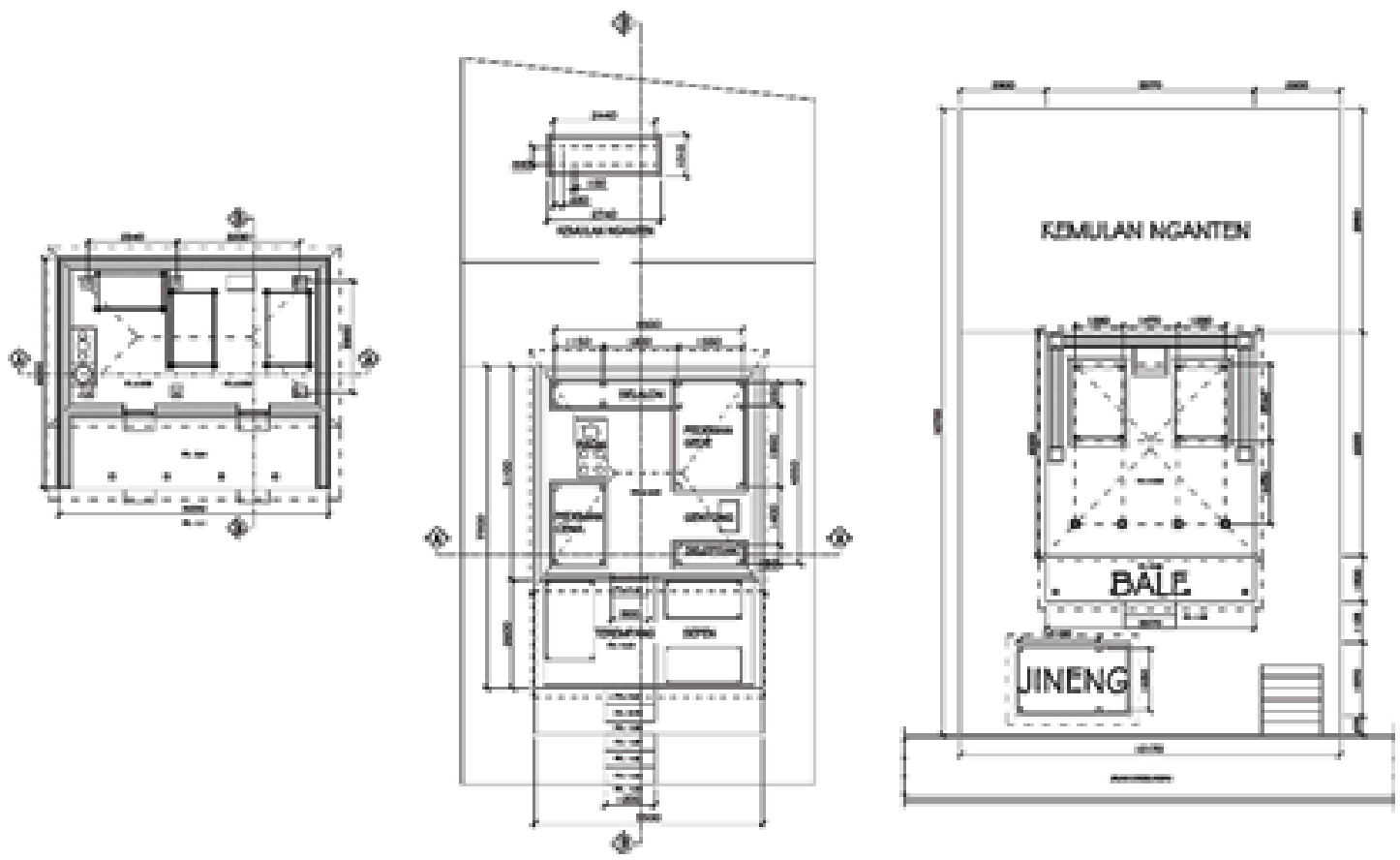

Figure 3: The layout of Bali Aga traditional house (source: Prajnawrdhi, 2017). 
Figure 3 described the simple BA house layout. A compact single house which could accommodate many different activities of the residents. This simple house has also small in size and has no ornament nor beautification to the homes as in BAP traditional houses. These houses harmonized with nature and its surrounding areas since the use of natural materials in the surrounding areas. Simplicity is the main concept of Bali Aga houses. The idea of simplicity has been implemented to the simple shape of the house, no ornamentation, the use of local materials, the truth of natural materials and structure used, simple wooden structure, simple and open plan for interior for more integrated spaces in the house, compact and multifunction interior design.

\section{Results and Discussion}

Contemporary houses which developed in Denpasar nowadays have a variety of forms and designs. One character that represents a contemporary house in Denpasar is the shape of a single way which compact and simple. This single and simple form of contemporary houses is created based on affordable land in the city center. Land limitations and high prices of the area in the city center are the impacts of too rapid population growth [10]. This happens to Denpasar which the rapid population growth derived from migration and the impact from tourism sector [13]. The simple form and lack of ornamentation or decoration on the building is a manifestation of the urban community busy lifestyle. Then, the house is designed to be more simple and easy in maintenance.

The demographics of the City of Denpasar which is very pluralistic become one of the challenges for architects and developers in designing a suitable house for their residents. The differences in customs, behaviors, lifestyle, and profession of prospective occupants are issues that must be solved. Some developers who develop contemporary houses in Denpasar have a global vision which is based on general conditions and situations and without conducting a specific behavioral approach to prospective users. Therefore, homes that are designed in some areas sometimes could not afford to accommodate the varied activities of their users. The transformation of the original design was carried out by the user to be able to provide the different needs of the inhabitants. This is due to a lack of personal understanding of prospective users as mentioned on the background that demographic changes from homogeneous society to heterogeneous referred to the need for knowledge of different types of user's characteristics. This has become a significant challenge for architects and developers to be able to design a comfortable dwelling for the occupants. A house should be able to 
accommodate all different levels of human needs from the lowest to the highest based on Maslow hierarchy, including ritual activities which also become self-actualization as the highest need of humans [15]. In some contemporary houses that have been built in Denpasar, most developers have provided empty open spaces on the north and east as areas which could be developed as the sacred area for a ritual purpose later.

Figure 4 shows two contemporary house designs which are located in Denpasar. It could be seen that the design of the house is a simple single house and each room in this building has a close relationship with each other just like the BA houses. The house plan in the middle and left part of the picture is a house that is reserved for the upper and middle class, while the house in the right part is the house provided for the middle to lower level. In a BA house, the orientation in the house is a space that can be used for various functions and is usually used as a communal area and gather with a family member because of its position is near the kitchen. Whereas in contemporary houses, the space that binds to other spaces is the dining room and family room. It can be seen here that there is an equality of concepts between contemporary houses and BA. There is a space/ room which unites all spaces in the house is a shared space for a family gathering. Whereas at BAP house, space which blends all different space function is an empty open space between buildings called Natah. This open space will have an essential function if there are traditional and religious ceremonies held in the house. However, in the daily use of the Natah is not the same as the use of the living room at the contemporary home or empty room of BA houses. One main character which could be seen on modern houses in Denpasar is the façade and the shape which applied clear and simple geometrical shapes. At the BA houses, the geometric shape of the building's facade is a combination of a triangular roof and a rectangular shape of the body of the buildings. In contemporary dwellings, the shape of the quadrilateral dominates through a simple rectangular shape composition. The use of materials in contemporary dwellings tends to use simple materials available in the field such as bricks, concrete blocks, and concrete. The use of simple materials, the sincerity of structure and simple geometric shapes without ornamentation and decorations in contemporary houses adopted similar concept to BA houses. The concept of simplicity and availability of materials in the surrounding environment are the main reason that underlies the concept of simple forms and the use of simple materials. The concept of open plan and integrated spaces in contemporary houses are also similar to the BA house concept; it let the space flows due to the limitation of land for the houses in Denpasar. 

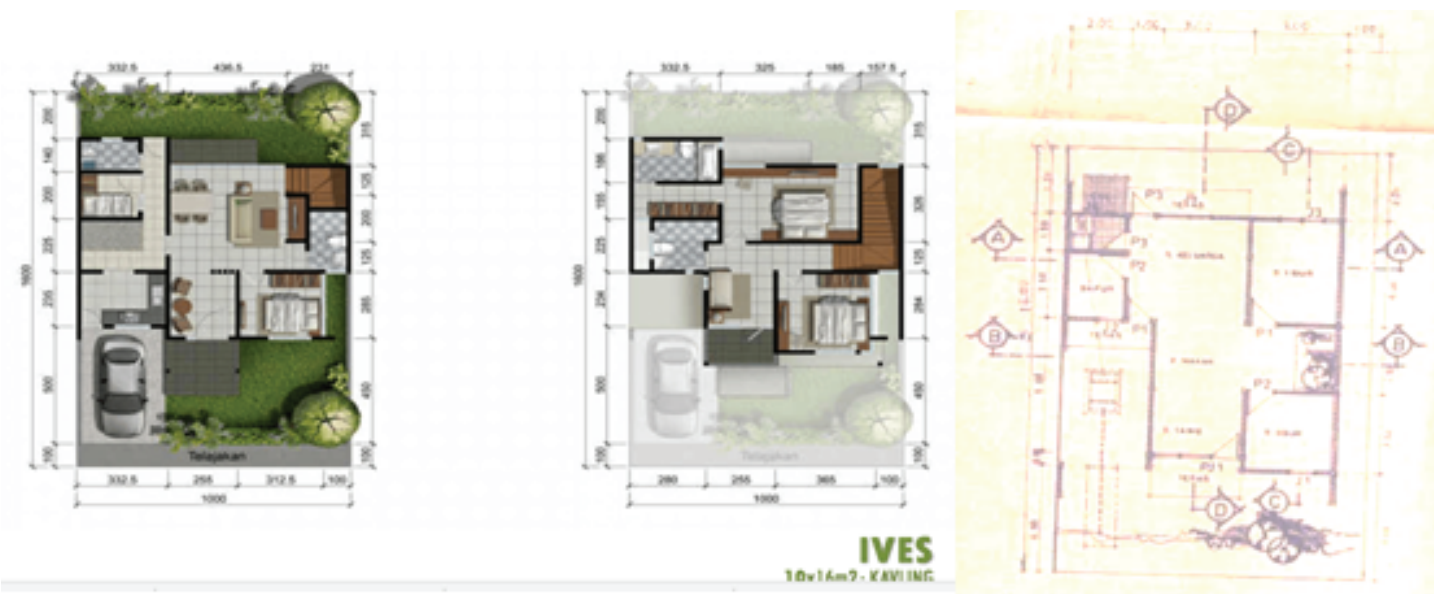

Figure 4: Left and middle: Plan of Citraland house Denpasar (source: Arsitag.com, 2018), Right: Plan Perumnas Monang Manning house Denpasar (source: Tegal Kerta village office, 2016).

Architecture is an artificial environment that is not only intended to connect human activities, and the environment, but at the same time is a means of cultural expression, to organize human physical, psychological and social life [6]. The most important thing that should be understood is that there are many different types of human activities to be accommodated in a house both physically and psychologically. Therefore the home must be able to help both essential human activities. A house is not only as a shelter but also as a place to stay which should be able to provide security and comfort, also reflects the personality and culture of its inhabitants [5]. Contemporary residences have not been fully able to give the identity of the occupants without any transformation carried out by the occupants. Contemporary residences in Denpasar and other areas are generally made in a massive number, but there are also some developers who have developed houses with designs that can accommodate the psychological needs of prospective residents in addition to physical needs. This type of housing is usually built in a smaller amount and at a relatively higher price. Based on a study of several kinds of contemporary residential houses in Denpasar, it shows that many homes can meet the needs of its users, however, still need an adaptation process with existing designs through some transformation of resident's behavior and physical spaces.

Housing problems are also related to the provision of housing for the community. It has become a critical problem, especially in developing countries. The problem that is the discrepancy between the needs and the existing dwelling supply; poor housing quality; the affordability; as well as social and cultural issues that cannot be accommodated in a house [20]. This is a classic problem which always faced in urban areas such as in Denpasar. To be able to solve this problem, coordination between the government and the private sector is needed, then it can provide houses for all levels of society. 
Affordable housing is one of the most important things for the community to be able to accommodate the influx of population and at the same time fulfill their needs. Blauw [4]; Bhatti \&Church [5] pointed that to solve housing problem is very important because the meaning of a house is not only as a shelter but also as a place to express culture and lifestyle both individually and in a social system. Therefore housing problems have become the most critical problems to be solved.

\section{Conclusion}

It can be concluded that contemporary residential houses in Denpasar put attention to the relationship of user's activities with designed spaces. However, mass production of these houses has not adjusted to the pre-prospective users who have different backgrounds. In the form of the building façade's concept, it shows that the concept of the building shape and the clarity of structure become the character of a contemporary house in Denpasar. Thus, the idea that is used in this house can be considered as the transformation of simplicity BA house concept. The idea of simplicity due to the location of these houses which are is built in the city center of Denpasar. Denpasar City as the capital of Bali faced a lack of affordable land for new developments, while the demand for housing is very high to accommodate the influx of population. Thus, this condition leads to new construction for settlements faced difficulty with applying the concept of BAP especially the Sanga Mandala land division and the house compound pattern with a variety of different functions. To conclude, the main purpose of a house can become a shelter, fulfilling physical and psychological needs such as traditional rituals and activities can be accommodated in contemporary houses in Denpasar. Though not all of the cultural activities could be carried out and provided as in the BAP house; there are only simple cultural and customary activities can be accommodated as simple traditional activities at BA houses. Contemporary houses can apply the transformation of the BA house concept in terms of size of the house, spaces being used, the land being used and the clarity of structure. Then, it can be stated that contemporary houses are not entirely a form of violation of Balinese culture, but more as adjusting the concept of Balinese culture into a modern lifestyle. Therefore the coordination between the government with the designers and developers is needed for new housing development or housing development infill. Design criteria for new housing development should be detailed into housing regulation to be able to sustain the values of Balinese culture in the future. 


\section{References}

[1] Adhika, I. M. (1994). Peran Banjar Dalam Penataan Komunitas, Studi Kasus Kota Denpasar. Bandung: Tesis Program S2 Jurusan Perencanaan Wilayah dan Kota ITB. Bandung: ITB.

[2] Arsitag [Internet]. Ballerina Park Cluster, Citraland Denpasar, 2018 [cited 1 August 2018]. Available from: https://www.arsitag.com/project/ballerina-park-cluster-atdenpasar-1/photo/2917.

[3] Bali Statistic Board (BPS) Bali. (2018). Laju Pertumbuhan Penduduk Hasil Sensus per Tahun.

[4] Blauw, P. W. (1994). The social and housing function of home and neighborhood. Housing Soc. Serv. Policy. 22-34.

[5] Bhatti, M., \& Church, A (2004). Home, the Culture of Nature and Meanings of Gardens in Late Modernity. Housing Study. 19 (1), 37-51.

[6] Boedojo et al. (1986). Arsitektur, Manusia dan Pengamatannya. Jakarta: Penerbit Djambatan.

[7] Budiharjo, E. (1986). Architectural Conservation in Bali. Yogyakarta: Gajah Mada University Press.

[8] Desa Tegal Kertha. (2018). Gambar Kerja Perumnas Monang-Maning, Desa Tegal Kertha, Denpasar Barat.

[9] Hitchcock, M., \& Putra, I. N. D. (2007). Tourism, Development and Terrorism in Bali. England: Ashgate Publishing Limited.

[10] Knox, P, L., McCarthy, L. (2005). Urbanization: an introduction to urban geography. 2nd ed. Prentice Hall, New Jersey.

[11] Marshall, A. [Internet]. Poscard from Bali. Time Magazine. 2011 [cited 18 April 2018]. Available from: http://content.time.com/time/magazine/article/0,9171,2063731,00.html.

[12] Parimin, A, P. (1986). Fundamental Study on Spatial Formation of Island Village: Environmental Hierarchy of Sacred Profane Concept in Bali. Thesis. Japan: Universitas Osaka.

[13] Prajnawrdhi, T. A. (2015). An approach to sustainable urban development and conservation of cultural heritage in developing countries: An investigation of Denpasar. Unpublished PhD Thesis. Australia: University of South Australia; 2015.

[14] Prajnawrdhi, T.A. (2017). Sanggah Kemulan Nganten Dan Pelangkiran: obyek penentu keberlangsungan rumah tradisional Bali Aga di Desa Pedawa- Kecamatan 
Banjar Kabupaten Buleleng, Bali. Jurnal RUAS. Malang. Universitas Brawijaya, 14 (2), 58-68.

[15] Prajnawrdhi, T. A. (2016). Tantangan konservasi pada Rumah Bandung Rangki dan Sri Dandan di Desa Bali Aga Pedawa, Buleleng-Bali. Proceeding Seminar Heritage Cirebon. 521-524.

[16] Redman, C. L., Jones, N. S. (2005). The Environmental, Social, and Health Dimensions of Urban Expansion. Population and Environment. 26 (6), 505-520.

[17] Samadhi, T. N. (2001). The urban design of Balinese town: Placemaking issues in the Balinese urban setting. Habitat International. 25 (4), 559-575.

[18] Samadhi, T. N. (2004). Making cosmo-religious landscapes: the design of a Balinese town's civic center (Bali, Indonesia). Habitat International. 28, 103-122.

[19] Sulistyawati. (1985). Preservasi Lingkungan Perumahan Pedesaan dan Rumah Tradisional Bali di Desa Bantas, Kabupaten Tabanan. Denpasar: P3M Universitas Udayana.

[20] Wakely, P. I., Schmetzer, H., Mumtaz, B. K. (1996). Urban housing strategies: education and realization. London: Pitman Publishing.

[21] Wiranatha, A, S., Smith, P, N. (2000). A Conceptual Framework for a Dynamic Model for Regional Planning: Toward Sustainable Development for Bali, Indonesia. International Conference on System Thinking in Management. 